https://cssr.uitm.edu.my/2018/

5th International Conference on Science and Social Research

Le Meridien Kota Kinabalu Hotel, 5 - 6 December 2018

\title{
The Flora Motif as Design Identity in Local Traditional Block Batik
}

\author{
Rabiatuadawiyah Kari' ${ }^{1}$, Mohd Azhar Samin², Rafeah Legino ${ }^{3}$ \\ 1Postgraduate Research Student, Faculty of Art \& Design, Universiti Teknologi MARA Shah Alam 40450 Selangor Malaysia \\ ${ }^{2}$ Faculty of Art \& Design, Universiti Teknologi MARA Shah Alam 40450 Selangor Malaysia \\ ${ }^{3}$ Formgiving Research Group, Faculty of Art \& Design, Universiti Teknologi MARA Shah Alam 40450 Selangor Malaysia
}

rubycarry91@yahoo.com, azharsamin@uitm.edu.my, rafeah@@uitm.edu.my

Tel: +60146772627

\begin{abstract}
This study discusses that floral motifs as the dominant traditional motifs in Malaysian block batik. In the 20th century, the block makers created any motif with purpose - the traditional block batik motifs not revealed due to lack of secure identity upon the development of high-tech modernisation. Based on the sequence of this issue, this study aims to classify the various types of local block motifs and designs. The classification base on their features using a suitable procedure. The crucial outcomes where the motifs of block batik still show the elements and innovation of the local motif identity.
\end{abstract}

Keywords: Block Batik; Design; Motif; Identity

eISSN: 2398-4287@ 2020. The Authors. Published for AMER ABRA cE-Bsby e-International Publishing House, Ltd., UK. This is an open access article under the CC BYNC-ND license (http://creativecommons.org/licenses/by-nc-nd/4.0). Peer-review under responsibility of AMER (Association of Malaysian Environment-Behaviour Researchers), ABRA (Association of Behavioural Researchers on Asians) and cE-Bs (Centre for Environment-Behaviour Studies), Faculty of Architecture, Planning \& Surveying, Universiti Teknologi MARA, Malaysia. DOI: https://doi.org/10.21834/ebpj.v5iSI3.2542

\subsection{Introduction}

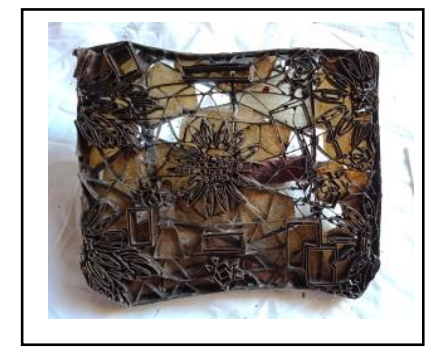

Fig 1: Sunflower block batik from 1988 (Source: Kak Yah, 2018)

The block printing or block stamping (see Fig. 1) is a unique technique that existed in the early history of the Malay civilisation. It is known as a piece of a wooden block with printed patterns stamped by hand on the fabric using natural dye. The motif and designs are

eISSN: 2398-4287@ 2020. The Authors. Published for AMER ABRA cE-Bsby e-International Publishing House, Ltd., UK. This is an open access article under the CC BYNC-ND license (http://creativecommons.org/licenses/by-nc-nd/4.0). Peer-review under responsibility of AMER (Association of Malaysian Environment-Behaviour Researchers), ABRA (Association of Behavioural Researchers on Asians) and cE-Bs (Centre for Environment-Behaviour Studies), Faculty of Architecture, Planning \& Surveying, Universiti Teknologi MARA, Malaysia.

DOI: https://doi.org/10.21834/ebpj.v5iSI3.2542 
permanent on the block and are applied repeatedly using one, two or more colours. The creation of the metal block transforms the manufacturing of stamped batik. The block batiks still produce in the East Coast states of Terengganu and Kelantan (Malaysian Handicraft Development Corporation, 2010). The block batik is a popular item, which use to decorate the fabric and continue to all generation.

\subsection{Structure}

This study also found that the floral motif in traditional craft is pertinent. The motif does not only demonstrate beautiful visuals but highlights the value of the design. The Malay culture includes the way of life and thoughts influence the appearance of the motifs. The motif also functions as a messenger to deliver the idea of the artisan to spectators. Besides, there are personal philosophies where visual moral teaching that provides a lesson and reminder to the Malay society at that time. Two methods usually used like oral and visual. Oral delivery includes advice, Malay poetic form (pantun), poetry and moral story whereas delivery in visual communication such as symbolic motif contains mainly. Also, the motif contains other direct and implied meanings as well as moral elements used as visual education tools and portrays the ethnicity of Malaysia. The motifs of fauna are changed from its original form as the requirement in Islamic religious teachings and are forbidden to expose the initial figure of Allah's creation. It was chosen as a reminder that sometimes it is all right to use a particular animal's motif for a lesson in daily life (Haron et al., 2014; Legino, 2004). Thus, it was replaced with the floral motif.

The close relationship between Malays and their environment resulted in the selection of the motifs. The bond occurs as the situation is deemed as a provider for necessities such as food, education, medicine, culture, customs, arts, attires, agriculture, merchandise and even belief. Furthermore, according to Ahmad Dawa (1995), the floral motifs are associated with herbs for healing and prevention, food, offerings, decoration and commemoration. Besides, floral motifs usually are often depicted as decoration at the vertical band (pinggir kain), head of cloth (kepala kain) and lower fringe (kaki kain) of the fabric. The creation of batik using floral motifs at the sarong cloth (kain sarong) and the full length of wrap-around cloth (kain belit) usually flaunts the local identity of the Malays (Ismail, 1986). Overall, the aforementioned justifies the use of floral motifs as dominant traditional motifs.

The floral motif of block batik cannot be separated from technology and sciences as many do not know that sciences and technology existed a long time ago in the Malay civilisation. The sciences can be explicitly seen in block batik's process, material (the invention of the block (sarang) evolves from potatoes, wood and brass. The block from metal more durable and can withstand the heat from the hot wax. Colour is the invention of the new batik dye evolves from natural colouring or dyes such as bunga dedap to obtain red colours until the discovery of synthetic colour. The creation of motifs inspires from the surrounding element like plants, fauna, geometric shape and abstract patterns (Haron \& Rahman, 2015). It is an urgent need to preserve this Malay block batik technology so that it will withstand in the modernisation. Therefore, this research focuses on the significant of floral motifs on the batik block.

Table 1. The total of the floral motif in traditional motif and new motif

\begin{tabular}{ll}
\hline & Type of Motif \\
\hline Name of the Traditional Motif & Name of the New Motif (Perbadanan Kemajuan Kraftangan Malaysia) \\
Floral (143) & Floral (8)
\end{tabular}

Table 1 shows the total flora motif in the traditional motif and a new motif. In the traditional motif, there are 143 collections of floral motifs. As for the new motif, there are eight collections of floral motifs. These two columns show the differences in the groups between traditional motif and the modern motif. Indeed, the conventional motif has more collections compared to the new motif.

\subsection{Tables}

Currently, the Malaysian batik does not have a strong identity as its counterpart, Indonesian batik (Syed Mahdzar, Chuah, \& Safari, 2013). The maker must create a specific Malaysian identity in block batik and recognise as a new product (Hussin et al., 2016). The current issues need to consider and attention. Based on the interview with a group of block batik entrepreneurs during the 2017 National Craft Day, the respondents claimed that block batik did not have a strong identity (see Table 2).

Table 2. Differences between traditional and current block batik in Malaysia

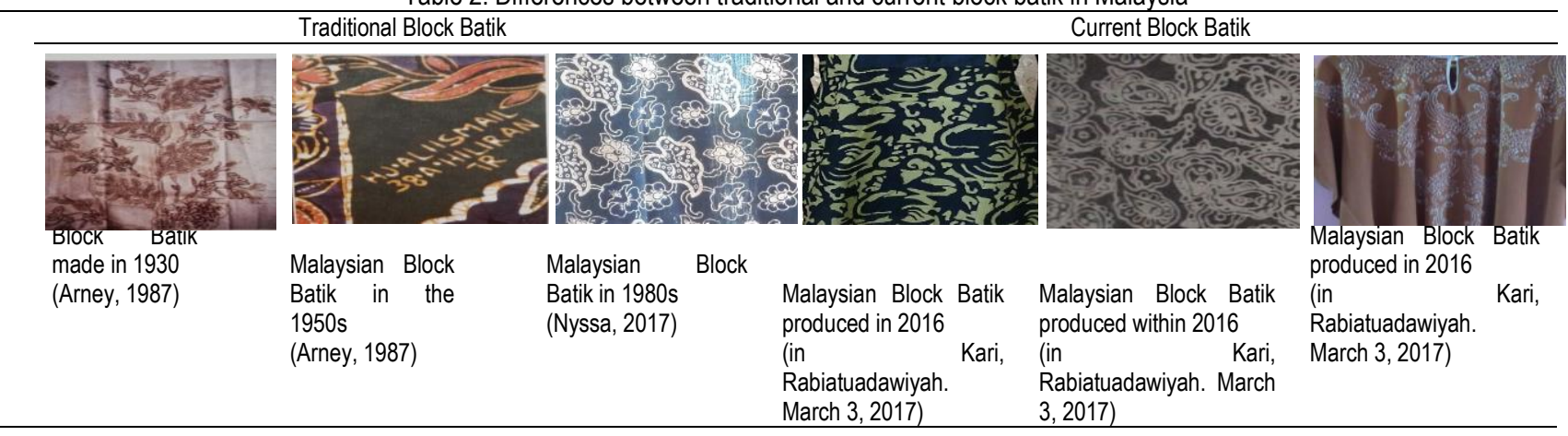


Table 2 displays the differences between traditional and current block batik in Malaysia. The former exhibits traditional motifs, and there are less traditional motifs for the latter. The modern producers of block batik could probably attribute this to a lack of understanding of the identities of traditional motifs. In this case, the designs were created based on imagination without taking into account the local block batik designs. Therefore, the latest products do not exhibit typical Malaysian designs. Overall, as per the literature, the current problems concerning Malaysian batik are in line with those associated with the contemporary local block batik. Hence, the research questions deduced are: what is the suitable process that can be used to classify the various types of local block batik design based on its features? Then, what are the ways to sustain the local block batik motif and design identity for the local batik industry?

\subsection{Method}

This research employed the qualitative approach with selected methods such as library research, fieldwork and interviews. Preliminary interviews of face-to-face were completed with 30 local block batik from various states. For the post-interview, as to achieve the first objective, open-ended with formal in-depth unstructured interviews were carried out. The respondents included local batik block makers, curators and Kraftangan Terengganu employees. In addition, the selected academicians are batik block experts. The researcher used the formal close-ended structure interviews with the group of the block batik experts and the batik block consumers to answer the second and third interview. Convenience sampling was employed due to the small population, and the area chosen was the cottage area. Overall, the characteristics of the sampling were based on their expertise in batik block from different places located in Malaysia. In addition, for data analysis, this research utilised the typology analysis to organise the data systematically. In addition, the framework is the adaptation of Zakaria Ali's theory. There are five keys in this theory, which are finesse (berhalus), usefulness (berguna), unity (bersatu), contrast (berlawanan), symbolism (berlambang) (Ali, 1989). The conceptual framework contains global themes to uplift appreciation and awareness of local motif and design batik block identity for sustainability. There are three significant variables known as organising themes, such as the local features, characteristics, and guidelines.

\subsection{Results and Discussion}

Table 3. Floral motif as the most dominant motif in the traditional motif and the new motif of local block batik

\begin{tabular}{|c|c|c|c|c|c|}
\hline \multicolumn{6}{|c|}{$\begin{array}{c}\text { Floral } \\
\end{array}$} \\
\hline & & & Name of Motif & & \\
\hline \multicolumn{5}{|c|}{ Traditional Motif } & \multirow[b]{2}{*}{ Chilli Flower } \\
\hline 1 & $\begin{array}{l}\text { Bunga Kemuning } \\
\text { (Wahab, 2016) }\end{array}$ & 11 & $\begin{array}{l}\text { Bunga Bakawali } \\
\text { (Wahab, 2016) }\end{array}$ & 1) & \\
\hline 2 & $\begin{array}{l}\text { Bunga } \\
\text { (Wahab, 2016) }\end{array}$ & 12 & $\begin{array}{l}\text { Bunga Dedap } \\
\text { (Wahab, 2016) }\end{array}$ & 2) & $\begin{array}{l}\text { Rafflesia } \\
\text { (Kraftangan Malaysia, 2017) }\end{array}$ \\
\hline 3 & $\begin{array}{l}\text { Lotus (Bunga } \\
\text { (Wahab, 2016) }\end{array}$ & 13 & $\begin{array}{l}\text { Buah Kecubong } \\
\text { (Wahab, 2016) }\end{array}$ & 3) & $\begin{array}{l}\text { Bougainvillea } \\
\text { (Kraftangan Malaysia, 2017) }\end{array}$ \\
\hline 4 & $\begin{array}{l}\text { Bunga } \\
\text { (Wahab, 2016) }\end{array}$ & 14 & $\begin{array}{l}\text { Bunga Seroja } \\
\text { (Wahab, 2016) }\end{array}$ & 4) & $\begin{array}{l}\text { Orchid } \\
\text { (Kraftangan Malaysia, 2017) }\end{array}$ \\
\hline 5 & $\begin{array}{l}\text { Rose (Bunga } \\
\text { (Wahab, 2016) }\end{array}$ & 15 & $\begin{array}{l}\text { Bus of Rose (Kudup Bunga Mawar) } \\
\text { (Ahmad, 2014) }\end{array}$ & 5) & $\begin{array}{l}\text { Kesidang } \\
\text { (Kraftangan Malaysia, 2017) }\end{array}$ \\
\hline 6 & $\begin{array}{l}\text { Hibiscus (Bunga Raya } \\
\text { (Wahab, 2016) }\end{array}$ & 16 & $\begin{array}{l}\text { Bud of Hibiscus (Kudup Bunga Raya) } \\
\text { (Ahmad, 2014) }\end{array}$ & $6)$ & $\begin{array}{l}\text { Bunga Bogor } \\
\text { (Kraftangan Malaysia, 2017) }\end{array}$ \\
\hline 7 & $\begin{array}{l}\text { Chrysanthemum (Bunga Kekwa) } \\
\text { (Ahmad, 2014) }\end{array}$ & 17 & $\begin{array}{l}\text { Rose (Bunga Mawar) } \\
\text { (Ahmad, 2014) }\end{array}$ & 7) & $\begin{array}{l}\text { Bunga Pekan } \\
\text { (Kraftangan Malaysia, 2017) }\end{array}$ \\
\hline 8 & $\begin{array}{l}\text { Sunflower (Bunga Matahari) } \\
\text { (Ahmad, 2014) }\end{array}$ & 18 & $\begin{array}{l}\text { Star Anise (Bunga Cengkih) } \\
\text { (Ahmad, 2014; Ismail, 1986) }\end{array}$ & 8) & $\begin{array}{l}\text { Mango Flower } \\
\text { (Kraftangan Malaysia, 2017) }\end{array}$ \\
\hline 9 & $\begin{array}{l}\text { Clove (Bunga Lawang) } \\
\text { (Ahmad, 2014; Ismail, 1986) }\end{array}$ & 19 & $\begin{array}{l}\text { Hibiscus (Bunga Raya) } \\
\text { (Ahmad, 2014) }\end{array}$ & 9) & $\begin{array}{l}\text { Chilli Flower } \\
\text { (Kraftangan Malaysia, 2017) }\end{array}$ \\
\hline 10 & $\begin{array}{l}\text { Bunga Kemboja } \\
\text { (Ahmad, 2014) }\end{array}$ & & & 10) & $\begin{array}{l}\text { Bunga Gambir } \\
\text { (Kraftangan Malaysia, 2017) }\end{array}$ \\
\hline & & & & 11) & $\begin{array}{l}\text { Bunga Lada Hitam } \\
\text { (Kraftangan Malaysia 2017) }\end{array}$ \\
\hline & & & & 12) & $\begin{array}{l}\text { Bunga Tanjung } \\
\text { (Kraftangan Malaysia, 2017) }\end{array}$ \\
\hline
\end{tabular}

Based on the research, Table 3 shows the floral motifs of the traditional motifs and the new motifs of local block batik. Under the traditional motifs, there are 19 collections and 12 collections of modern motifs. Indeed, the traditional motifs have more selection compared to the new motif. This finding is essential to conserve the motifs of block batik so that society will recognise more of the local motifs and be proud of their heritage. 
Table 4. The small parts of characteristic identities in the floral motif that exists in the traditional motif and the new motif in local block batik Floral

\begin{tabular}{|c|c|c|c|c|c|c|c|}
\hline \multicolumn{8}{|c|}{ Characteristic Identities } \\
\hline & & & Traditional Motif & & & & New Motif \\
\hline 1 & $\begin{array}{l}\text { Symbol: } \\
\text { Bunga Kukuran (Ahmad } \\
\text { Dawa, 1995) }\end{array}$ & 8 & $\begin{array}{l}\text { Decoration: } \\
\text { Bunga Cempaka (Ahmad, } \\
\text { 2014) }\end{array}$ & 14 & $\begin{array}{l}\text { State/Race: } \\
\text { Lotus (Teratai) (Ahmad Dawa, } \\
\text { 1995) }\end{array}$ & 1 & $\begin{array}{l}\text { Symbol: } \\
\text { Rafflesia } \\
\text { (Kraftangan Malaysia, 2017) }\end{array}$ \\
\hline 2 & $\begin{array}{l}\text { Medicine: } \\
\text { Bunga Bebalik Angin } \\
\text { (Bebaling) (Ahmad Dawa, } \\
\text { 1995) }\end{array}$ & 9 & $\begin{array}{l}\text { Food: } \\
\text { Sunflower (Bunga Matahari) } \\
\text { (Ahmad, 2014) }\end{array}$ & 15 & $\begin{array}{l}\text { Guidance: } \\
\text { Tanjung Tua (Ahmad Dawa, } \\
\text { 1995) }\end{array}$ & 2 & $\begin{array}{l}\text { Medicine: } \\
\text { Bunga Gambir } \\
\text { (Kraftangan Malaysia, 2017) }\end{array}$ \\
\hline 3 & $\begin{array}{l}\text { Smell: } \\
\text { Rose (Bunga Mawar ) } \\
\text { (Ahmad, 2014) }\end{array}$ & 10 & $\begin{array}{l}\text { Education: } \\
\text { Lotus (Bunga Teratai) (Abd } \\
\text { Wahab, 2016) }\end{array}$ & 16 & $\begin{array}{l}\text { Caring/Nurturing: } \\
\text { Tanjung Tua (Ahmad Dawa, } \\
\text { 1995) }\end{array}$ & 3 & $\begin{array}{l}\text { Decoration: } \\
\text { Bunga Pekan } \\
\text { (Kraftangan Malaysia, 2017) }\end{array}$ \\
\hline 4 & $\begin{array}{l}\text { Ceremonial Offering: } \\
\text { Hibiscus (Bunga Raya) } \\
\text { (Ahmad Dawa, 1995) }\end{array}$ & 11 & $\begin{array}{l}\text { Accessory: } \\
\text { Ylang Ylang and Roses } \\
\text { Derahman (Personal } \\
\text { Communication, August 20, } \\
\text { 2017) }\end{array}$ & 17 & $\begin{array}{l}\text { Strength: } \\
\text { Flower Bamboo (Bunga Buloh } \\
\text { (Ahmad Dawa, 1995) }\end{array}$ & 4 & $\begin{array}{l}\text { Food: } \\
\text { Bunga Lada Hitam } \\
\text { (Kraftangan Malaysia, 2017) }\end{array}$ \\
\hline 6 & $\begin{array}{l}\text { Surrounding Sources: } \\
\text { Pumpkin (Bunga Labu) } \\
\text { (Ahmad, 2014) }\end{array}$ & 12 & $\begin{array}{l}\text { Fertility: } \\
\text { Bunga Pasu (Ahmad Dawa, } \\
\text { 1995) }\end{array}$ & 18 & $\begin{array}{l}\text { Marriage: } \\
\text { Mango Leaves (Bunga Manga) } \\
\text { Derahman } \quad \text { (Personal } \\
\text { communication, August } 20,2017 \text { ) }\end{array}$ & 5 & $\begin{array}{l}\text { Education: } \\
\text { Chilli Flower } \\
\text { (Perbadanan Kemajuan } \\
\text { Kraftangan Malaysia, 2017) }\end{array}$ \\
\hline 7 & $\begin{array}{l}\text { Uniqueness: } \\
\text { Bunga Senduduk (Ahmad, } \\
\text { 2014) }\end{array}$ & 13 & $\begin{array}{l}\text { Sex: } \\
\text { Caperdik (Ahmad } \\
\text { 1995) }\end{array}$ & & & 6 & $\begin{array}{l}\text { Guidance: } \\
\text { Bunga Tanjung } \\
\text { (Kraftangan Malaysia, 2017) }\end{array}$ \\
\hline
\end{tabular}

Based on the study, Table 4 shows the specific identity from a small part of the floral motif. The table above shows the differences in the floral motif that have a unique character includes the traditional motif and the new motif of local block batik. Under the column of traditional motif, 18 characteristics depict the identities of the traditional motif such as symbol, medicine, smell, ceremonial offering, surrounding sources, uniqueness, decoration, food, education, accessory, fertility, sex, state/race, guidance, caring/nurturing, strength, and marriage. As of the new motif, there are six distinctive identities; symbol, medicine, decoration, education, and food. These two columns aim to show the special character of floral motif that is shared between traditional motifs and new motifs, which are five, namely symbol, medicine, decoration, food and education.

Furthermore, the collection of traditional motifs is more than a new motif. Thus, the current block batik fabric is less restricted than the classic motif and resulted in less identity. The block batik maker created the motifs based on the traditional motifs, imagination and as well as intuitiveness. Therefore, the analysis of floral motif is aimed to contribute to the body of knowledge, economic growth, sociology aspect and sciences with technology. The unique findings need to be revealed as part of the body of knowledge to society. The existence of these exclusive motifs of block batik is made known as part of local identity which needs to be preserved and cherished so that it will sustain throughout the globalisation.

Moreover, the significant findings must be shared with the society to attract to the affection towards modern block batik fabric style, which is a combination of the traditional and modern motif and matches with the current fashion trend. Indirectly, this will also attract the tourists to know and learn about this unique local identity of block batik motifs and designs. As a result, the domestic textile and tourism industry will flourish and also will contribute to the economic growth of Malaysia. This exciting finding needs to be made known among the society because these floral motifs will add to the sociology aspect in Malaysia. These motifs will unite the multi races in Malaysia to wear the block batik garment with local motifs because it is the national attire and not restricted to particular groups or race only. This local motif is very versatile and can be worn by anyone for any event or activities. Besides, this important finding will conserve the block batik motif, as it is a part of history, science and technology of motif creation that can be extended to the next generation as part of their heritage.

\subsection{Conclusion}

This research has recognised and categorised the floral of the traditional motif and the new motif of block batik based on the typology analysis to sustain the local identity in the block batik. Based on the findings, it can be concluded that the essential results are that the current local block batik does not have a strong identity because the availability of block batik in the market does not portray the floral motif extensively. The interesting findings were that the Malaysian block batik of the floral motif had a distinct characteristic identity (see table 4); these are likely to assist significantly in reinforcing the local character and hence, the sustainability of the block batik industry. Based on the findings, specific batik practitioner of the society still prefers to use the traditional floral motifs. Noor Arfa Batik and Ruzz Gahara, both are prominent local batik companies and have managed to preserve the heritage motifs. For example, Ruzz Gahara produced mesmerising batik collection, which grabs the world attention at the Who's Next Paris fashion show in 2013. Since then, the groups were featured in the pages of UK's Tatler Magazine, British Vogue, and highlighted in the Passage to Malaysia documentary by Travel and Living Channel (TLC). This high acceptance from society mainly at the global level proves that the traditional floral motifs are highly in demand by the current community where they still favour and appreciate the local motifs. Collectively, this study outlined a critical role for Malaysia's block batik maker in emphasising fresh design and motif based on the local 
identity. It is recommended that future researchers study the uniqueness of plant motif of block batik in each village, especially in Kelantan and Terengganu, Malaysia in preserving the local identity.

\section{Acknowledgements}

This project was financially supported under grant No. 600-IRMI/MyRA5/3/GIP (026/2017) of Universiti Teknologi MARA. With the extensive cooperation of the teams, this study was able to be conducted smoothly-furthermore, our appreciation to those involved in this study.

\section{References}

Ahmad, A., Abbas, M. Y., Mohd Taib, M. Z., \& Masri, M. (2015). Wall carving decoration and motifs influences spatial, social interaction: Is it intentional or accidental? Procedia - Social and Behavioural Sciences, 202, 311-321.

Ahmad Dawa, M. N. (1995). The symbolism of batik from Kelantan, Malaysia: Its origin and transformation (Doctoral dissertation). Manchester Metropolitan University, Manchester.

Ahmad, K. (2014). Transformasi motif blok batik semasa dari tahun 1960 hingga 2009 (Doctoral dissertation). Universiti Pendidikan Sultan Idris, Perak.

Ali, Z. (1989). Seni dan seniman: Esei-esei seni halus. Kuala Lumpur, Malaysia: Dewan Bahasa dan Pustaka.

Arney, S. (1987). Malaysian batik: Creating new tradition. Kuala Lumpur, Malaysia: Kraftangan Malaysia.

Haron, H. Yusof, N. A., Taha, M., \& Mutalib, N. A. (2014). Motifs of nature in Malay traditional craft. Middle East Journal of Scientific Research, 21(1), 169-180. doi: 10.5829/idosi.mejsr.2014.21.01.21132

Haron., N., Ramli., Z. \& Nik Abdul Rahman, N. K. S. (2015, November). Evolusi perkembangan blok batik di negeri Kelantan. Retrieved from https://www.researchgate.net/publication/305284073_Evolusi_perkembangan_blok_batik_di_negeri_Kelantan

Hussin, H., Husain, K., Pilus, A., Hasan, H., Cheong, K. M., \& Mohd Yaacob, N. (2016). Innovation of Malaysian batik craft in arts: A reflection for vocational education. Social Sciences, 11(12), 2983-2986. doi: 10.3923/sscience.2016.2983.2986

Ismail, S. Z. (1986). Rekabentuk kraftangan Melayu tradisi. Kuala Lumpur, Malaysia: Dewan Bahasa dan Pustaka.

Legino, R. (2004). A study of the Islamic influence on traditional Malay Batik Sarongs of Kelantan and Terengganu (MA Thesis, Universiti Teknologi MARA).

Malaysian Handicraft Development Corporation. (2010). Heritage textile: An insight of a civilisation. Kuala Lumpur, Malaysia: Malaysian Handicraft Development Corporation.

Perbadanan Kemajuan Kraftangan Malaysia. (2017). Bunga identiti negeri 2017. Kuala Lumpur: Perbadanan Kemajuan Kraftangan Malaysia.

Syed Mahdzar, S. S., Chuah, P. J., \& Safari, H. (2013). Development of historical culture tourism industry through batik art to attract the local and tourist. Malaysia Batik Art Integrated Centre, 2013/2014, Semester 2. Retrieved from https://www.academia.edu/8331766/Malaysia_Batik_Art_Integrated_Centre

The Peak. (2017). Bloom of Batik. Retrieved from https://www.pressreader 